\title{
Individualized teaching programming for a virtual learning environment: development of content concerning nursing records
}

\author{
Patrícia de Carvalho Nagliate ${ }^{1}$ \\ Elyrose Sousa Brito Rocha ${ }^{2}$ \\ Simone de Godoy ${ }^{3}$ \\ Alessandra $\mathrm{Mazzo}^{3}$ \\ Maria Auxiliadora Trevizan ${ }^{4}$ \\ Isabel Amélia Costa Mendes ${ }^{4}$
}

\begin{abstract}
Objective: Describe the planning of contents on nursing records for use in a virtual learning environment, based on Individualized Teaching Programming, a didactic resource that uses basic principles of behavioral analysis. Method: Final objectives were specified, after defining the intermediary components to achieve each final objective, as well as the preliminary requirements for each intermediary component. At the end of this process, teaching activities were planned and organized in steps the students need to develop. Results: By breaking up the contents into behaviors, seven action categories emerged: impartiality, organization, honesty, objectiveness, coherence, readability and discernment. Conclusion: the use of Individualized Teaching Programming as a didactic resource to plan contents on nursing records is feasible to identify the units and modules for the development of a course in a virtual learning environment for nursing professionals.

Descriptors: Education, Nursing; Nursing; Nursing Education Research; Nursing Records; Educational Technology.
\end{abstract}

\footnotetext{
${ }^{1}$ Doctoral Student, Escola de Enfermagem de Ribeirão Preto, Universidade de São Paulo, WHO Collaborating Centre for Nursing Research Development, Brazil.

2 PhD, Adjunct Professor, Universidade Estadual do Piauí, Brazil.

3 PhD, Professor, Escola de Enfermagem de Ribeirão Preto, Universidade de São Paulo, WHO Collaborating Centre for Nursing Research Development, Brazil.

${ }^{4}$ PhD, Full Professor, Escola de Enfermagem de Ribeirão Preto, Universidade de São Paulo, WHO Collaborating Centre for Nursing Research Development, Brazil.
} 


\title{
Programação de ensino individualizado para ambiente virtual de aprendizagem: elaboração do conteúdo registro de enfermagem
}

Objetivo: descrever o planejamento de conteúdo sobre registro de enfermagem para utilização em ambiente virtual de aprendizagem, fundamentado na Programação de Ensino Individualizado, recurso didático que utiliza princípios básicos da análise do comportamento. Método: foram especificados objetivos terminais, definidos os componentes intermediários para a consecução de cada objetivo terminal, assim como os requisitos antecedentes para cada componente intermediário. Ao fim desse processo, foram planejadas e organizadas as atividades de ensino em passos a serem desenvolvidos pelos aprendizes. Resultados: ao desmembrar o conteúdo em comportamentos, sete categorias de ações emergiram: imparcialidade, organização, honestidade, objetividade, coerência, legibilidade e discernimento. Conclusão: a utilização da Programação de Ensino Individualizado, como recurso didático para o planejamento de conteúdo sobre registro de enfermagem, mostrou-se viável para identificar as unidades e módulos para o desenvolvimento do curso em ambiente virtual de aprendizagem, para profissionais de enfermagem.

Descritores: Educação em Enfermagem; Enfermagem; Pesquisa em Educação de Enfermagem ; Registros de Enfermagem; Tecnologia Educacional.

\section{Programación de enseñanza individualizada para ambiente virtual de aprendizaje: elaboración del contenido registro de enfermería}

\begin{abstract}
Objetivo: Describir la planificación de contenido sobre registro de enfermería, para utilización en ambiente virtual de aprendizaje, con base en la Programación de Enseñanza Individualizada, un recurso didáctico que utiliza principios básicos del análisis del comportamiento. Método: fueron especificados objetivos finales, definidos los componentes intermediarios para alcanzar cada objetivo terminal, así como requisitos antecedentes para cada componente intermediario. Al final de ese proceso, fueron planeadas y organizadas las actividades de enseñanza en pasos que serán desarrollados por los aprendices. Resultados: Al desmembrar el contenido en comportamientos, siete categorías de acciones emergieron: imparcialidad, organización, honestidad, objetividad, coherencia, legibilidad y discernimiento. Conclusión: la utilización de la Programación de Enseñanza Individualizada como recurso didáctico para la planificación de contenido sobre registro de enfermería se mostró viable para el desarrollo del curso en ambiente virtual de aprendizaje para profesionales de enfermería.
\end{abstract}

Descriptores: Educación en Enfermería; Enfermería; Investigación en Educación de Enfermería; Registros de Enfermería; Tecnología Educacional.

\section{Introduction}

Nursing records, which are used as one of the main means of communication among healthcare professionals, are flawed in that they are subject to written errors. These errors can lead to adverse events that directly influence patient safety ${ }^{(1-2)}$.

The medical staff observes and understands patient needs through both verbal and nonverbal communication. As there are many professionals involved in any particular patient's care, clear and effective communication is critical to ensure the quality and continuity of care ${ }^{(3-4)}$.

Clinical environments are often dynamic and complex and, as such, present many challenges for effective communication between health professionals. Under such conditions, adverse events can occur ${ }^{(5)}$. Poor communication is the most common cause of these events in health care environments and can result in problems ranging from delays in treatment to surgical and medication errors ${ }^{(6-7)}$.

The notes recorded in patient records are a form of ongoing communication between members of a healthcare team. They help health professionals to plan efficient, high-quality medical interventions to restore a patient's health(8-9).

The information contained in the nursing notes reflects the care and treatment provided to patients 
throughout their period of hospitalization. They should explain all relevant events clearly, since these records form part of the legal responsibilities of the profession(7,10-11). As such, the records can be used for a range of purposes e.g. surveys, audits, lawsuits, strategic planning etc. ${ }^{(11-12)}$.

Despite the legal importance of nursing records, in many cases we found that written communication has been overlooked by health professionals. Their failure to record information in an accurate and timely fashion, as well as the difficulty in accessing vital information contained in the medical records, significantly increase the risk of harming the patient, which could lead to disastrous consequences for their care(5). Moreover, various initiatives indicate that it is possible to prevent adverse events such as surgical site infections by implementing protocols and ensuring comprehensive record keeping(13).

The relationship between the presence and quality of information provided in the records of hospitalized patients and the occurrence of adverse events is weak, suggesting that the components of the records are less valued when related to such events. In contrast, the quality of information concerning the patient was found to be deficient and had a high correlation with adverse events $^{(2)}$.

Moreover, in a recent study the quality of nursing records at a university hospital was audited and, of the 424 patient records analyzed, (26.7\%) were classified as poor, $(64.6 \%)$ as regular and only $(8.7 \%)$ as good. This clearly demonstrates the need for investment in improvement in this area(10).

The literature provides us with many studies that highlight the errors often made by nurses in recording their activities ${ }^{(2,14-15)}$. Reflecting on this and the urgent need to implement measures to rectify the situation, we can see a clear need to adopt educational strategies to help nurses to develop and improve their record-keeping skills. We believe that implementing such teaching activities could have a positive impact on the current situation, especially as ICT-based training can encourage the interplay of practical knowledge and up-to-date scientific theory and thus encourage professionals to adopt new practices.

This concept of education (e-learning) has been identified by researchers as being in tune with the changing context of education today. Although this entails the reorganization of the training process, e-learning has been shown to be revolutionary in providing broad, comprehensive and permanent access to education ${ }^{(16)}$.
In any case, we should always keep in mind that innovative projects of continuing professional development in nursing should be harmonized with criteria that favor the understanding of individuals in their professional context in the improvement process, enabling reflective and creative ways of thinking and doing, aiming the personal, social, and professional development of the citizen-worker(16).

In choosing a methodology to plan and develop the content of such training, we took into account the fact that nurses are required to constantly update their knowledge and skills in a range of professional practices, as well as the requirement that training be adjusted to the dynamic conditions of the profession. We were also concerned with offering training which was targeted but at the same time provided the necessary depth to be appropriate for continuing professional development training for nurses to access through online distance learning in virtual learning environments.

Taking all of these factors into consideration, we decided to use the Personalized System of Instruction (PSI) to plan and develop the content of training on nursing records.

In PSI the student is placed at the center of the learning process, in that they progress in a series of small steps that adapt according to an individual's performance. PSI differs from traditional teaching in five key aspects, offering: individualized pace, division of disciplinary content into small steps, classes and demonstrations for motivational purposes only, an emphasis on written material that can be accessed by the student at their convenience and finally, the importance of a monitor / mentor to provide immediate feedback ${ }^{(17-18)}$.

According to the literature, PSI and distance learning are closely related in several aspects: both are instructional, use the written word (virtual or printed) and require careful preparation of teaching materials and content ${ }^{(19)}$, since the methodology allows participants to access all course content whenever necessary or convenient $(18,20)$.

In this context, we believe that the best strategy for continuing professional development on recordkeeping is to use distance learning tools, particularly those available in virtual learning environments, in conjunction with PSI. This should make the training convenient, accessible and compatible with the timeconstraints and realities of the nursing profession.

Thus, in this study we aim to describe how we planned the course content for e-training on nursing records based on PSI. 


\section{Method}

This is a descriptive study of the planning of PSI-based course content for training on nursing records to be provided online in a virtual learning environment. The course was developed between January 2012 and July 2012.

The PSI process consists of the following fifteen steps: 1) choose the theme or topic; 2 ) describe the problem to be solved; 3) specify the overall behavioral goals; 4) propose the behavioral goals; 5) justify the relevance of the goals in relation to the participants; 6 ) analyze the goals in terms of the intermediate components/objectives necessary to achieve them; 7) organize the intermediate outcome objectives which result from this analysis into a teaching sequence; 8) plan learning activities to enable participants to achieve each intermediate outcome objective in the sequence; 9) organize these activities into units or steps to be performed by the participant; 10) plan the procedure for evaluating the effectiveness of the teaching program; 11) organize the material be used by learners in different units within the program; 12) write instructions for each work unit; 13) plan procedures to assess the participant's performance; 14) draft a presentation of the teaching program including goals, resources, procedures and evaluation system; 15) communicate and examine the teaching program in terms of behavior ${ }^{(21)}$.

We began this study by establishing an overall goal with reference to the question: what is best practice for completing nursing records? Then, we identified specific behavioral goals and analyzed the intermediate steps needed to achieve each of these goals. From this, we defined the prerequisites for each intermediate step and finally planned and organized the sequence of educational activities to be performed by participants.

Our starting point was to decide what results we wanted to see and how we expected participants to behave when faced with similar situations in the real world. We went on to determine what must be taught to the learner so that these results can be achieved. Finally, we broke the intermediate components (behavior outcome objectives) down into simpler sub-behaviors.

An intermediate component is so-called as it is a smaller, simpler behavioral objective than that expressed by the overall goal. They are necessary for the learner to be able to accomplish the final goal of the training.

We identified and described all of the intermediate components, which were relevant to the behavioral goals. Based on these intermediate components, we proposed teaching activities in which the participant will be able to practice, master and display each of these behavioral objectives.

We planned training exercises for each intermediate component and then organized these activities into units or steps to be followed by learners. This was done taking into account the appropriate tools for each proposed activity available in a virtual learning environment.

In this study, we followed nine of the fifteen steps recommended in the literature. The six remaining steps were not addressed because they are related to the development, implementation and evaluation of PSI content.

\section{Results}

One of the starting points for planning a teaching activity is to identify the issue or question to be addressed by the training. The fundamental question for this education program was thus: what is best practice for completing nursing records?

With this in mind, we present a description of the both the general and specific behavior classes that enabled us to identify seven goals. These were based on the dominant functions needed for best practice in nursing records: organization, fairness, honesty, consistency, objectivity, legitimacy and knowledge (Figure 1).

\begin{tabular}{|c|c|c|c|}
\hline & General behavior classes & Specific behavior classes & Dominant function \\
\hline \multirow{9}{*}{ Recording } & \multirow{2}{*}{$\begin{array}{l}\text { Recording in an organized } \\
\text { manner }\end{array}$} & \multirow{2}{*}{ Record situations and facts logically and sequentially } & $\begin{array}{l}\text { Knowledge: recording skills and text } \\
\text { cohesion }\end{array}$ \\
\hline & & & $\begin{array}{l}\text { Evaluation: the situations in which one } \\
\text { must record nursing activities }\end{array}$ \\
\hline & $\begin{array}{l}\text { Recording in an impartial } \\
\text { manner }\end{array}$ & $\begin{array}{l}\text { Record activities and facts without personal opinions } \\
\text { and bias }\end{array}$ & Knowledge: about impartiality \\
\hline & $\begin{array}{l}\text { Recording in an honest } \\
\text { manner }\end{array}$ & $\begin{array}{l}\text { Record activities in such as way as they and reliable } \\
\text { and reflect reality }\end{array}$ & Knowledge: about reliability \\
\hline & $\begin{array}{l}\text { Recording in an objective } \\
\text { manner }\end{array}$ & Record activities and facts concisely & Knowledge: about objectivity \\
\hline & \multirow{2}{*}{$\begin{array}{l}\text { Recording in an coherent } \\
\text { manner }\end{array}$} & Record activities and facts cohesively & \multirow{2}{*}{ Knowledge: about cohesion } \\
\hline & & Record activities and facts coherently & \\
\hline & $\begin{array}{l}\text { Recording in an legible } \\
\text { manner }\end{array}$ & Record activities, ideas and facts legibly & Knowledge: about legibility \\
\hline & $\begin{array}{l}\text { Recording in an conscious } \\
\text { manner }\end{array}$ & $\begin{array}{l}\text { Identify the nursing activities/situations which ought to } \\
\text { be recorded }\end{array}$ & $\begin{array}{l}\text { Knowledge: about which activities/ } \\
\text { situations ought to be recorded }\end{array}$ \\
\hline
\end{tabular}

Figure 1- General and specific behavior classes expected from nursing professionals to ensure: "Best practice for nursing records ". Ribeirão Preto, SP, Brazil, 2012 
Teaching activities were planned based on each specific display whilst completing the units, along with the prerequisite component. Below, we present the behavior that participants must skills, which facilitate the mastery of each objective (Figure 2).

\begin{tabular}{|c|c|c|}
\hline Prerequisite skills & Intermediate components & $\begin{array}{l}\text { Outcome } \\
\text { objectives }\end{array}$ \\
\hline $\begin{array}{l}\text { 1. record attentively } \\
\text { 2. respect cephalocaudal order } \\
\text { 3.respect the logical order of report writing: beginning, middle and end }\end{array}$ & $\begin{array}{l}\text { Record activities in a logical and sequential } \\
\text { manner: throughout the shift; confidently and } \\
\text { consciously; with adequate resources }\end{array}$ & $\begin{array}{l}\text { Recording in an } \\
\text { organized manner }\end{array}$ \\
\hline $\begin{array}{l}\text { 1. respect the personal opinion of others } \\
\text { 2. record activities without preconceived ideas }\end{array}$ & $\begin{array}{l}\text { Record activities without personal opinions } \\
\text { and bias }\end{array}$ & $\begin{array}{l}\text { Recording in an } \\
\text { impartial manner }\end{array}$ \\
\hline $\begin{array}{l}\text { 1.record activities immediately after they are performed } \\
\text { 2. record activities in their exact sequence } \\
\text { 3. describe activities in a comprehensive manner } \\
\text { 4. follow ethical and legal guidelines }\end{array}$ & $\begin{array}{l}\text { Record activities and facts in such a way that } \\
\text { they faithfully reflect reality }\end{array}$ & $\begin{array}{l}\text { Recording in an } \\
\text { honest manner }\end{array}$ \\
\hline 1. record activities clearly and objectively & Record activities concisely & $\begin{array}{l}\text { Recording in an } \\
\text { objective manner }\end{array}$ \\
\hline $\begin{array}{l}\text { 1. guarantee harmony between elements of the text } \\
\text { 2. write sentences and paragraphs that are clearly connected to clarify } \\
\text { meaning }\end{array}$ & $\begin{array}{l}\text { Record activities and facts in a coherent } \\
\text { manner }\end{array}$ & $\begin{array}{l}\text { Recording in a } \\
\text { coherent manner }\end{array}$ \\
\hline $\begin{array}{l}\text { 1. describe activities in such a way that there is a logical relationship } \\
\text { between ideas and a meaningful context } \\
\text { 2. describe activities and facts logically and without contradictions } \\
\text { 3. make reference to terms and expressions previously used in the text } \\
\text { 4.record ideas in a linear fashion }\end{array}$ & Record activities in a cohesive manner & $\begin{array}{l}\text { Recording in a } \\
\text { cohesive manner }\end{array}$ \\
\hline $\begin{array}{l}\text { 1.record activities in such a way that they are comprehensible } \\
\text { 2. record using clear handwriting and without corrections } \\
\text { 3. follow proper procedures when written errors occur } \\
\text { 4. use acronyms and abbreviations appropriately }\end{array}$ & $\begin{array}{l}\text { Record activities, ideas and facts in an } \\
\text { intelligible manner }\end{array}$ & $\begin{array}{l}\text { Recording in a } \\
\text { legible manner }\end{array}$ \\
\hline $\begin{array}{l}\text { 1. recognize the importance of nursing records } \\
\text { 2. record activities soon after they are undertaken } \\
\text { 3. recognize nursing practices that must be recorded: admission, transfer, } \\
\text { discharge, death, complications, progression of the disease, and hydration } \\
\text { and biological controls } \\
\text { 4. recognize the ethical and legal requirements of nursing practice and } \\
\text { record-keeping } \\
\text { 5. sign and stamp the record }\end{array}$ & Identify activities which ought to be recorded & $\begin{array}{l}\text { Recording in a } \\
\text { conscious manner }\end{array}$ \\
\hline
\end{tabular}

Figure 2 - description of outcome objectives, intermediate components and prerequisites for general and specific behavior classes. Ribeirão Preto, SP, Brazil, 2012

After describing the skills to be mastered by the participants, we organized activities into units or steps to be followed. We chose to give instructions on how to complete nursing records, followed by practical exercises. To enable the participants to master the skills or display the desired behavior classes in each unit, we included texts, descriptions of best practice, examples and videos.

We developed three modules and shown below is the work plan related to each, with descriptions of units, steps, objectives and suggested activities. The content of the introduction and communication units is shown in Figure 3, whilst the units on the textual aspects of record-keeping are shown in Figures 4 and 5.

\begin{tabular}{|c|c|c|c|}
\hline Units & Steps & Objectives & Suggested Activities \\
\hline \multirow{5}{*}{$\begin{array}{l}\text { 1.General aspects } \\
\text { of nursing records }\end{array}$} & $\begin{array}{l}\text { 1. What are } \\
\text { nursing records? }\end{array}$ & $\begin{array}{l}\text { 1. Reaffirm the significance } \\
\text { of nursing records }\end{array}$ & $\begin{array}{l}\text { 1. Text about the significance of nursing records. } \\
\text { 2. Word search exercise based on this text }\end{array}$ \\
\hline & $\begin{array}{l}\text { 2. How important } \\
\text { are nursing } \\
\text { records? }\end{array}$ & $\begin{array}{l}\text { 2. Reaffirm the importance } \\
\text { of record-keeping in the } \\
\text { wide variety of situations } \\
\text { nurses come across }\end{array}$ & $\begin{array}{l}\text { 1. Text concerning the importance of nursing records in a wide range of } \\
\text { nursing situations } \\
\text { 2. Hangman exercise to find the key word related to the text. }\end{array}$ \\
\hline & $\begin{array}{l}\text { 3. What should be } \\
\text { included in nursing } \\
\text { records? }\end{array}$ & $\begin{array}{l}\text { 3. Review the nursing } \\
\text { situations which ought to } \\
\text { be recorded }\end{array}$ & $\begin{array}{l}\text { 1. Case study about what should be included in nursing records } \\
\text { 2. Exercise: recreate a record for the student to develop a record based on } \\
\text { the content worked on this case study. }\end{array}$ \\
\hline & $\begin{array}{l}\text { 4. When should } \\
\text { nursing records be } \\
\text { completed? }\end{array}$ & $\begin{array}{l}\text { 4. Reaffirm how safety } \\
\text { and continuity of care are } \\
\text { affected by nursing records }\end{array}$ & $\begin{array}{l}\text { 1. Case study on what should be included in nursing records } \\
\text { 2. Word scramble exercise using keywords from the text. }\end{array}$ \\
\hline & $\begin{array}{l}\text { 5. Where should } \\
\text { nursing records be } \\
\text { recorded? }\end{array}$ & $\begin{array}{l}\text { 5. Review the documents } \\
\text { that exist and are likely } \\
\text { to be used for recording } \\
\text { purposes in the healthcare } \\
\text { system }\end{array}$ & $\begin{array}{l}\text { 1. Text about the types of documents that exist and are likely to be used for } \\
\text { recording purposes in the healthcare system. } \\
\text { 2. Exercise to link the types of documents with the information to be recorded. }\end{array}$ \\
\hline
\end{tabular}


Nagliate PC, Rocha ESB, Godoy S, Mazzo A, Trevizan MA, Mendes IAC.

\begin{tabular}{|l|l|l|l|}
\hline \multicolumn{1}{|c|}{ Units } & \multicolumn{1}{|c|}{ Steps } & \multicolumn{1}{c|}{ Objectives } & \multicolumn{1}{c|}{ Suggested Activities } \\
\hline $\begin{array}{l}\text { 2.The history of } \\
\text { record-keeping }\end{array}$ & $\begin{array}{l}\text { 6. Review the historical } \\
\text { aspects upon which the } \\
\text { practices of record- } \\
\text { keeping are based }\end{array}$ & 1. Text about the history of nursing records \\
\hline $\begin{array}{l}\text { 3.The importance } \\
\text { of communication }\end{array}$ & $\begin{array}{l}\text { 7. Reaffirm the importance } \\
\text { of written and oral } \\
\text { communication }\end{array}$ & $\begin{array}{l}\text { 1. Video on oral communication, short text on written reports and key } \\
\text { elements of writing. } \\
\text { 2. Exercise to reinforce content: written report on a nursing situation liable to } \\
\text { be recorded. }\end{array}$ \\
\hline
\end{tabular}

Figure 3 - Work plan for the units "General aspects of nursing records", "The history of record-keeping" and "The importance of communication" to be used in continuous professional development training on nursing records.

Ribeirão Preto, SP, Brazil, 2012

\begin{tabular}{|c|c|c|c|}
\hline Units & Steps & Objectives & Suggested Activities \\
\hline \multirow{3}{*}{$\begin{array}{l}\text { 1.Legibility of } \\
\text { texts }\end{array}$} & $\begin{array}{l}\text { 1.Comprehensible } \\
\text { texts }\end{array}$ & $\begin{array}{l}\text { 1. Record nursing activities in such as } \\
\text { way as they are comprehensible. }\end{array}$ & $\begin{array}{l}\text { 1. Text about text comprehensibility } \\
\text { 2. Sort a disorganized/incomprehensible nursing record }\end{array}$ \\
\hline & $\begin{array}{l}\text { 2A.Handwriting } \\
\text { 2B.Corrections } \\
\text { 2C.Spelling }\end{array}$ & $\begin{array}{l}\text { 2A. Reaffirming the importance of } \\
\text { handwriting } \\
\text { 2B. How to deal with mistakes in } \\
\text { nursing records } \\
\text { 2C.Purging nursing records of common } \\
\text { spelling mistakes }\end{array}$ & $\begin{array}{l}\text { 1. Text on handwriting and written corrections } \\
\text { 2. Exercise to edit and rewrite a text which illegibly and has } \\
\text { written corrections and spelling mistakes in order to make it } \\
\text { comprehensible. }\end{array}$ \\
\hline & $\begin{array}{l}\text { 3. Health acronyms } \\
\text { and abbreviations }\end{array}$ & $\begin{array}{l}\text { 3. Review the most commonly used } \\
\text { nursing acronyms and abbreviations }\end{array}$ & $\begin{array}{l}\text { 1. Text about acronyms and abbreviations in the healthcare area } \\
\text { 2. Exercise to link terms with their appropriate acronym. }\end{array}$ \\
\hline \multirow{5}{*}{$\begin{array}{l}\text { 2.Cohesion } \\
\text { and coherence } \\
\text { in texts }\end{array}$} & 1.Meaning in texts & $\begin{array}{l}\text { 1. Understand the importance of } \\
\text { meaning and significance in written } \\
\text { phrases }\end{array}$ & $\begin{array}{l}\text { 1. Text on the meaning and significance of a phrase } \\
\text { 2. Exercise to search for badly written/ambivalent phrases in a } \\
\text { nursing record and rewrite them. }\end{array}$ \\
\hline & 2.Logic in texts & $\begin{array}{l}\text { 2. Understand the importance of the } \\
\text { internal logic of sentences (cohesion) }\end{array}$ & $\begin{array}{l}\text { 1. Text about logic in nursing records } \\
\text { 2. Exercise to rewrite illogical sentences. }\end{array}$ \\
\hline & $\begin{array}{l}\text { 3.Contradiction in } \\
\text { texts }\end{array}$ & $\begin{array}{l}\text { 3. Understand the importance of } \\
\text { writing texts free of contradictions }\end{array}$ & $\begin{array}{l}\text { 1. Presentation of a contradictory nursing record and the safety risk } \\
\text { it poses to a patient } \\
\text { 2. Case study exercise to create a contradictory nursing record, } \\
\text { which would have negative consequences for a patient. }\end{array}$ \\
\hline & $\begin{array}{l}\text { 4. Terms and } \\
\text { expressions in } \\
\text { texts }\end{array}$ & $\begin{array}{l}\text { 4. Review the official terms and } \\
\text { expressions used in the Portuguese } \\
\text { language }\end{array}$ & $\begin{array}{l}\text { 1. Presentation of a nursing record that contains both correct and } \\
\text { incorrect terms and expressions } \\
\text { 2. Exercise to create a nursing record which uses terms and } \\
\text { expressions appropriate to its purpose }\end{array}$ \\
\hline & 5.Linearity in texts & $\begin{array}{l}\text { 5. Review the importance of harmony } \\
\text { between the textual elements of a } \\
\text { nursing record }\end{array}$ & $\begin{array}{l}\text { 1. Presentation of a well-written nursing record, which uses terms } \\
\text { and expressions effectively. } \\
\text { 2. Crossword exercise using descriptions of aspects of textual } \\
\text { linearity }\end{array}$ \\
\hline
\end{tabular}

Figure 4 - Work plan for the units "Legibility of texts" and "Cohesion and coherence in texts" to be used in continuous professional development training on nursing records. Ribeirão Preto, SP, Brazil, 2012

\begin{tabular}{|c|c|c|c|}
\hline Units & Steps & Objectives & Suggested Activities \\
\hline $\begin{array}{l}\text { 3. Objectivity in } \\
\text { texts }\end{array}$ & 1. Clarity in texts & $\begin{array}{l}\text { 1. Highlight the importance of the ability } \\
\text { to quickly understand ideas in a text }\end{array}$ & $\begin{array}{l}\text { 1. Presentation of a nursing record which is not objective the } \\
\text { consequences this has on patient safety. } \\
\text { 2. Exercise to clarify a nursing record to make it more objective/ } \\
\text { clearer }\end{array}$ \\
\hline \multirow{3}{*}{$\begin{array}{l}\text { 4. Honesty in } \\
\text { texts }\end{array}$} & $\begin{array}{l}\text { 1. Texts which } \\
\text { reflect reality }\end{array}$ & $\begin{array}{l}\text { 1. Highlight the importance of recording } \\
\text { activities and facts in the exact } \\
\text { sequence in which they took place. }\end{array}$ & $\begin{array}{l}\text { 1. Video of a nursing situation, followed by an evaluation of how a } \\
\text { subsequent nursing record does not reflect what really happened } \\
\text { 2. Exercise to write a nursing record of what happened in the video } \\
\text { in such as way as to reflect the events. }\end{array}$ \\
\hline & $\begin{array}{l}\text { 2. Omitting facts in } \\
\text { nursing records }\end{array}$ & $\begin{array}{l}\text { 2. Understand the need for records } \\
\text { to truly reflect the nursing activities } \\
\text { performed. }\end{array}$ & $\begin{array}{l}\text { 1. Presentation of a nursing record in which pertinent facts have } \\
\text { been omitted. } \\
\text { 2. Gap-fill exercise to complete nursing record with key words. }\end{array}$ \\
\hline & $\begin{array}{l}\text { 3. Ethical precepts } \\
\text { and professional } \\
\text { responsibility }\end{array}$ & $\begin{array}{l}\text { 3. Highlight ethical aspects of the } \\
\text { nursing profession in terms of record- } \\
\text { keeping }\end{array}$ & $\begin{array}{l}\text { 1. Text which deals with the ethical aspects of record-keeping } \\
\text { 2. Gap-fill exercise to complete nursing record with key words }\end{array}$ \\
\hline \multirow{2}{*}{$\begin{array}{l}\text { 5. Impartiality } \\
\text { in texts }\end{array}$} & & $\begin{array}{l}\text { 5. Understand the needs to respect the } \\
\text { opinions of others }\end{array}$ & \multirow{2}{*}{$\begin{array}{l}\text { 1. Texts which deals with the ethical aspects of record-keeping } \\
\text { 2. Word search exercise to find words from a nursing record which } \\
\text { express personal opinions or bias. }\end{array}$} \\
\hline & & $\begin{array}{l}5 \mathrm{~A} . \text { Record activities without personal } \\
\text { bias. }\end{array}$ & \\
\hline
\end{tabular}

(The Figure 5 continue in the next page...) 


\begin{tabular}{|c|c|c|c|}
\hline Units & Steps & Objectives & Suggested Activities \\
\hline \multirow{3}{*}{$\begin{array}{l}\text { 6. Organization } \\
\text { in texts }\end{array}$} & & $\begin{array}{l}\text { 6. Highlight the importance of } \\
\text { organization in texts. }\end{array}$ & \multirow{3}{*}{$\begin{array}{l}\text { 1. Text which deals with the importance of textual organization and } \\
\text { cephalocaudal note-taking } \\
\text { 2. Exercise to organize a nursing record }\end{array}$} \\
\hline & & $\begin{array}{l}\text { 6A. Highlight the importance of } \\
\text { cephalocaudal note-taking }\end{array}$ & \\
\hline & & $\begin{array}{l}\text { 6B. Understand the logic of written } \\
\text { texts: beginning, middle and end }\end{array}$ & \\
\hline
\end{tabular}

Figure 5 - Work plan for the units "Objectivity in texts", "Honesty in texts" ,Impartiality in texts" and "Organization in texts" to be used in continuous professional development training on nursing records. Ribeirão Preto, SP, Brazil, 2012

\section{Discussion}

With the goal of ensuring best practice in completing nursing records in mind, we identified specific behavior classes, which should be encouraged during training in order that students are able to meet the prerequisites and master each behavioral outcome objective. Thus, the unit descriptions and intermediate steps were established depending on the prerequisites needed to achieve a desirable outcome.

Breaking these requirements down into intermediate steps helped us to identify what behaviors the learner needed to develop in order to reach the final goal of best practice. It was necessary to check the student's initial level of performance and understanding, since it is only by observing this starting point that we can decide to what level of complexity the outcome objectives need to be broken down into. When the level of complexity of the intermediate steps is consistent with the student's initial level, there is no need to further break down the behavior into smaller components. In doing so, a training program should help to diminish the errors that participants make, as making mistakes generally has an adverse effect of a student's learning. The most effective way to keep the student motivated and allow them to effectively learn the target behavior is by eliminating or minimizing such mistakes(22).

Experts highlight the fact that when using PSI, the course content is carefully divided into small units and that student can only progress from one unit to the next when they have demonstrated mastery of the previous unit. This reduces the likelihood of a student experiencing difficulties in learning the new content due to the fact that they didn't understand some previous related content ${ }^{(20)}$.

Based on this method, each student will undergo their training step by step at their own pace and will be closely monitored by the tutor, who gives individual feedback. If the student does not meet the learning criterion of a particular unit, he may revise the content and try again. This is a stark contrast to traditional methods, in which participants are forced to move along to the next unit at the pace of his colleagues or the program schedule.

The description of what the learner should be able to do at the end of the learning experience takes the form of a statement about the way in which they should go on to behave in real-world situations(21).

Assessment of each unit can take various forms within PSI, e.g. multiple choice questions, gap-fills, short written responses, practical demonstrations of a particular skill, oral tests etc. ${ }^{(20)}$

The training program breaks the topic down into units to be offered in small steps and in doing so provides a clear and objective overview of what should be learnt throughout the course. Furthermore, we believe that making the content available in a virtual learning environment allows for greater interaction between the tutor and the student in that positive feedback is required throughout the course.

During the planning and development of this course, our decision-making was always informed by the aim to offer an efficient and personalized course. These characteristics allow the professional to undergo training at their own pace and whenever it is convenient to their everyday lives. Moreover, the tasks are organized into steps, meaning that the learner can only progress to the next step when they have mastered the previous unit. Throughout this process, they receive mentoring and constant feedback.

An important consideration regarding the use of PSI for ongoing professional development for nurses is that the student completes each module relatively quickly during this type of training. In this it differs from other methods of training that require the student to dedicate all of their time to completing the course 
content. PSI methodology also allows participants enrolled in the same course to work on different units, depending on their rate of progress. Unlike traditional training methods, a self-study program recognizes and responds to individual participants and does not penalize participants who need more time to learn ${ }^{(19)}$.

Breaking down best practice for nursing records into units was very time consuming. However, we believe that this detailed scrutiny of "nursing records", or indeed any other topic, is of fundamental importance if we wish to plan comprehensive, detailed training. This procedure demands that the programmer think critically about the content of each unit and ensures that no salient points are missed out. Good planning also requires that we establish clear outcomes and goals, i.e. that we know how to clearly specify the behaviors that we wish to observe in our participants at the end of the process, as well as provide the most appropriate conditions for these behaviors to be acquired and maintained. Effective training of this type is particularly crucial as health providers are increasing concerned with providing ongoing professional development to their staff(23)

\section{Conclusion}

We found using a personalized education program to plan and develop course content for training on nursing records a viable option. It helped us in identifying the units and modules we needed to develop for nursing professionals within a virtual learning environment. Using PIS allowed us to develop organized, objective, clear, detailed and rich topic content on the issue addressed.

However, one possible drawback of this method is that it is very time-consuming in terms of planning and requires a lot of preparation and dedication on the part of the programmer.

We hope that when this content is used for training purposes it will facilitate the learning process, since it was conceived in a series of steps in order to respect the pace and time constraints of each online participant.

\section{References}

1. The Joint Commission. National Patient Safety Goals. The Joint Commission. [Internet. Washington D.C (USA); 2012. [acesso 15 mar 2012]. Disponível em: http:// www.jointcommission.org/standards_information/ npsgs.aspx

2. Zegers M, Bruijne MC, Spreeuwenberg P, Wagner C, Groenewegen, PP, Wal GVD. Quality of patient record keeping: An indicator of the quality of care? BMJ Qual Saf. 2011;20:314-8.

3. Zoehler KG, Lima MADS. Opinião dos auxiliares de enfermagem sobre a passagem de plantão. Rev Gaúcha Enferm. 2000; 21(2):110-24.

4. Lyndon A, Zlatnik MG, Wachter RM. Effective physician-nurse communication: a patient safety essential for labor and delivery. Am J Obstet Gynecol. 2011 Aug;205(2):91-9.

5. Goldsmith D, Boomhower M, Lancaster DR, Antonelli M, Kenyon MAM, Benoit A, Chang F, Dykes PC. Development of a nursing handoff tool: $A$ webbased application to enhance patient safety. AMIA Annu Symp Proc. [Internet]. 2010; [acesso 20 mar 2012]; 2010:256-60. Disponível em: http://www.ncbi.nlm.nih. gov/pmc/articles/PMC3041387/

6. Gandhi TK. Fumbled handoffs: One dropped ball after another. Ann Intern Med. 2005;142(5):352-8.

7. Kutney-Lee A, Kelly D. The effect of hospital electronic health record adoption on nurse-assessed quality of care and patient safety. J Nurs Adm. 2011;41(11):466-72.

8. Angerami EL, Mendes IAC, Pedrazanni JC. Análise crítica das anotações de enfermagem. Rev Bras Enferm. 1976;29:28-37.

9. Jefferies D, Johnson M, Nicholls D, Lad S. A wardbased writing coach program to improve the quality of nursing documentation. Nurse Educ Today. 2012 Aug;32(6):647-51. Epub 2011 Oct 5.

10. Setz VG, Innocenzo MD. Avaliação da qualidade dos registros de enfermagem no prontuário por meio da auditoria. Acta Paul Enferm. 2009;22(3):313-7.

11. Kron T, Gray A. Administração dos cuidados de enfermagem ao paciente: colocando em ação as habilidades de liderança. 6a ed. Rio de Janeiro (BRA) Interlivros; 1989. 320 p.

12. Matsuda LM.; Carvalho ARS, Évora YDM. Anotações/ registros de enfermagem em um hospital-escola. Cienc Cuid Saude. 2007;6(supl.2):337-46

13. Peñalver-Mompeán MD, Saturno-Hernández, PJ, Fonseca-Miranda Y, Gama ZAS. Assessment of protocols for surgical-site preparation in a regional network of hospitals. Rev. Latino-Am. Enfermagem. [Periódico na Internet]. abril 2012 [acesso 12 mar 2012]; 20(2):316-24. Disponível em: http://www. scielo.br/scielo.php?script=sci_arttext\&pid=S0104 $11692012000200014 \&$ Ing $=$ en\&nrm $=$ iso

14. Santos SR, Paula AFA, Lima JP. Nurses and their perception about the manual recording system in patients' files. Rev. Latino-Am. Enfermagem. [Periódico na Internet. 2003 [acesso 10 mar 
2012]; 11(1):80-7. Disponível em: http://www. scielo.br/scielo.php?script $=$ sci_arttext\&pid $=$ S0104$11692003000100012 \&$ lng $=e n \& n r m=$ iso 15. Paans W, Sermeus W, Nieweg RMB, Van Der Schans CP. Prevalence of accurate nursing documentation in patient records. J Adv Nurs. 2010;66(11):2481-9.

16. Trevizan MA, Mendes IAC, Mazzo A, Ventura CAA. Investment in nursing human assets: education and minds of the future. Rev. Latino-Am. Enfermagem. [Periódico na Internet].2010 [acesso 20 mar 2012]; 18(3):467-71. Disponível em: http://www.scielo. br/scielo.php?script=sci_arttext\&pid=S0104$11692010000300024 \&$ lng $=e n \& n r m=$ iso

17. Keller FS. "Good-bye teacher" JABA. 1968; 1:79-89. 18. Springer JA, Iannotti NV, Kane, MD, Haynes K, Sprague JE. Instructional design and assessment: Pharmacogenomics training using an instructional software system. Am J Pharm Educ. 2011 Mar;75(2):32. 19. Grant LK, Spencer RE. The personalized system of instruction: Review and applications to distance education. IRRODL. [internet]. 2003 [acesso 2 set 2011]; 4:1-17. Disponível em: http://www.irrodl.org/ index.php/irrodl/article

20. Todov JC, Moreira, MB, Martone RC. Sistema Personalizado de Ensino, Educação à Distância e Aprendizagem Centrada no Aluno. Psicol Teor Pesq. julset $2009 ; 25(3): 289-96$.

21. Botomé SP. Objetivos comportamentais no ensino: a contribuição da análise experimental do comportamento [tese de doutorado]. Ribeirão Preto (SP): Departamento de Psicologia de Ribeirão Preto da Universidade de São Paulo; 1980. 279 p.

22. Frare AVE, Souza FC, Queiroz FP, Luca, GG, Moskorz L, Kubo OM. Avaliação de um programa para ensinar comportamento empático para crianças em contexto clínico. Interação Psicol. 2005;9(2):355-69.

23. Rocha ESB, Nagliate PC, Furlan CEB, Rocha Jr K, Trevizan MA, Mendes IAC. Knowledge management in health: a systematic literature review. Rev. LatinoAm. Enfermagem. abr. 2012; [acesso 30 out 2012]; 20(2): 392-400. Disponível em <http://www. scielo.br/scielo.php?script=sci_arttext\&pid=S0104$11692012000200024 \&$ lng=pt\&nrm=iso $>$. http://dx.doi. org/10.1590/S0104-11692012000200024. 